See discussions, stats, and author profiles for this publication at: https://www.researchgate.net/publication/331314833

\title{
From Rock-Buffered to Open Fluid System During Emplacement of the Lower Pedraforca Thrust Sheet (South Pyrenees)
}

Chapter · February 2019
DOI: 10.1007/978-3-030-01575-6_52

CITATIONS

0

4 authors:

David Cruset

Geosciences Barcelona (Geo3Bcn) CSIC

30 PUBLICATIONS 75 CITATIONS

SEE PROFILE

Irene Cantarero

University of Barcelona

68 PUBLICATIONS 189 CITATIONS

SEE PROFILE
6. Jaume Vergés

Geosciences Barcelona (Geo3Bcn) CSIC 312 PUBLICATIONS 10,271 CITATIONS

SEE PROFILE

61 University of Barcelona

180 PUBLICATIONS 1,538 CITATIONS

SEE PROFILE

Some of the authors of this publication are also working on these related projects:

Growth Strata in the Central Zagros fold-and-thrust belt, Dehdasht area View project

Tectonic inversion of a basement-involved fold-and-thrust belt: Temporal and structural evolution of the Kopet Dagh (NE Iran) and its implications for the ArabiaEurasia collision history View project 


\title{
From rock-buffered to open fluid system during emplacement of the Lower Pedraforca thrust sheet (South Pyrenees)
}

\author{
David Cruset $^{1 *}$, Jaume Vergés ${ }^{2}$, Irene Cantarero ${ }^{1}$ and Anna Travé ${ }^{1}$ \\ ${ }^{1}$ Departament de Mineralogia, Petrologia i Geologia Aplicada, Facultat de Ciències de la Terra, \\ Universitat de Barcelona (UB), Martí i Franquès s/n, 08028, Barcelona. \\ ${ }^{2}$ Institut de Ciències de la Terra Jaume Almera, ICTJA-CSIC, Lluís Solé i Sabaris s/n, 08028 \\ Barcelona. \\ *Corresponding author: d.cruseteub.edu
}

\begin{abstract}
The evolution of fluid flow during the emplacement of the Lower Pedraforca thrust sheet is inferred from fracture data, petrography and geochemistry of calcite cements.

The results show that during the earlier stages of compression, fluids migrating along fractures were in equilibrium with their adjacent host rocks. In contrast, external fluids in disequilibrium with their adjacent host rock migrated along fractures during the later stages of emplacement of the thrust sheet.

Similar evolution has been observed in other areas of the Pyrenees and other orogens worldwide.
\end{abstract}

Keywords: South Pyrenean fold and thrust belt, Fluids, Fractures.

\section{Introduction}

The cements precipitated in fractures record the composition and evolution of fluids during the tectonic history of fold and thrust belts [1].

In this work we define the evolution of fluids during the development of the Lower Pedraforca thrust sheet (South Pyrenees) integrating structural, petrographic and geochemical data. The results are compared with previous works done in the Southern Pyrenees (Jaca, Vallfogona and L'Escala thrusts, Ainsa Basin and Puig-reig anticline) and other orogens worldwide (Bighorn Basin and North Oman and Canadian Rocky Mountains) [2].

\section{Geological setting}

The south Pyrenean fold and thrust belt (SPFTB) consists of a south-directed thrust system emplaced from Late Cretaceous to Oligocene detached predominantly above Triassic and Eocene evaporites [3].

The studied structure is the Lower Pedraforca thrust sheet (LPTS), an imbricated thrust system emplaced during the Lutetian (Middle Eocene) [4]. It consists of an allochthonous klippe detached above Eocene sediments and constituted of Lower Triassic 
38 evaporites, Lower Jurassic limestones and dolostones, Upper Cretaceous limestones 39 (Areny Fm.), Paleocene continental deposits (Garumnian) and Eocene syn-orogenic 40 sediments deposited in the thrust front [3].

\section{Methodology}

Field work consisted of fracture data acquisition (dip directions and dips) and sampling of calcite cements precipitated in fractures and host rocks for petrographic and geochemical studies. Fracture data were plotted in stereograms and restored with respect to host rock bedding to define different fracture sets. Petrographic observations of 26 polished thin sections were made using optical and cathodoluminescence microscopy to define different calcite cements and their crosscutting relationships. The Geochemical characterization of fluids consists of carbon- and oxygen-isotope analysis of fracture-filling cements and their adjacent carbonate host rocks.

\section{$4 \quad$ Fractures and cements}

Up to seven fracture sets have been identified in the studied area. F1 and F2 fractures comprise N-S and E-W bed-perpendicular veins, respectively. F2 is abutting F1, indicating a later time of formation. F3 fractures consist of bed-parallel slip surfaces. F4 consists of conjugated NW-SE and NE-SW bed-perpendicular veins abutting F1and F2. F5 consists of conjugated NNE-SSW and NW-SE veins associated to major thrusts cross-cutting bedding at high angle. F6 and F7 include small and major south-verging thrusts and strike-slip faults cross-cutting bedding at high angle, respectively.

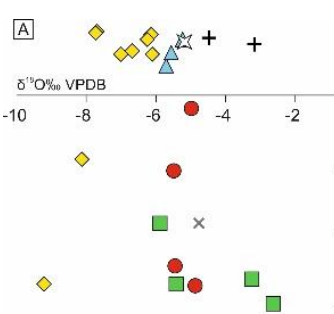

Fig. 1. A) $\delta^{18} \mathrm{O}$ vs $\delta^{13} \mathrm{C}$ cross-plot of calcite cements and host rocks and B) $\delta^{18} \mathrm{O}_{\text {calcite cement }}$ Vs $\delta^{18} \mathrm{O}_{\text {host rock }}$ cross-plot from calcite cements of the LPTS. 
The petrographic study of fracture fillings in the LPTS have allowed to identify six types of calcite cements. $\mathrm{Cc} 1$ consists of non-luminescent microsparite precipitated in the intergranular and moldic porosity of the Areny Fm. Cc2 consists of non-luminescent sparite precipitated in vug porosity affecting the Garumnian. Cc3 consists of orange luminescent sparite crystals, blocky or elongated parallel to fracture walls precipitated in F1, F2 and F3 fractures and vug porosity postdating $\mathrm{Cc} 1$ and $\mathrm{Cc} 2$. Cc4 consists of dull to orange luminescent sparite precipitated in F1, F2 and F4 affecting Eocene synorogenic sediments. Cc5 consists of zoned non-luminescent to dull orange cement precipitated in F1, F2 and F4 fractures postdating the previous cements. Cc6 consists of dull-brown sparite precipitated in F4, F5, F6 and F7 postdating Cc5.

Marine carbonates from the Areny Fm. have $\delta^{13} \mathrm{C}$ between +1.5 and $+1.7 \%$ VPDB and $\delta^{18} \mathrm{O}$ between -4.5 and $-3.2 \%$ VPDB. Garumnian palustrine limestones have $\delta^{13} \mathrm{C}$ between -17.5 and $-3.7 \%$ VPDB and $\delta^{18} \mathrm{O}$ between -8.2 and $-4.8 \%$ VPDB (Fig. 1A). $\mathrm{Cc} 1$ has a $\delta^{13} \mathrm{C}$ of $+1.5 \%$ VPDB and $\delta^{18} \mathrm{O}$ of $-5.2 \%$ VPDB. $\mathrm{Cc} 2$ has a $\delta^{13} \mathrm{C}$ of -10.1 $\%$ VPDB and $\delta^{18} \mathrm{O}$ of $-6 \%$ VPDB. For $\mathrm{Cc} 3$, the $\delta^{13} \mathrm{C}$ ranges between -10.8 and -0.4 $\%$ VPDB and the $\delta^{18} \mathrm{O}$ between -5.5 and $-3.9 \%$ VPDB. Cc4 has $\delta^{13} \mathrm{C}$ values between -5.9 and $-3.7 \%$ VPDB and $\delta^{18} \mathrm{O}$ between -5.9 and $-2.6 \%$ VPDB. Cc5 has $\delta^{13} \mathrm{C}$ values between +0.8 and $+1.6 \%$ VPDB and $\delta^{18} \mathrm{O}$ ranging between -5.7 and $-4.4 \%$ VPDB. For Cc6, the $\delta^{13} \mathrm{C}$ ranges between -15.2 and $+1.8 \%$ VPDB and the $\delta^{18} \mathrm{O}$ between -9.2 and $-6.1 \%$ VPDB.

\section{Discussion}

Crosscutting relationships between fractures and bedding in the LPTS indicates that F1 to F4 formed during the first stages of compression, whereas F5 to F7 formed during the last stages of deformation once strata were already folded [5].

The $\delta^{13} \mathrm{C}$ of all the calcite cements are similar to their host rocks, indicating a rockbuffered system. Likewise, the $\delta^{18} \mathrm{O}$ values of $\mathrm{Cc} 2$ and $\mathrm{Cc} 3$ are also in equilibrium with their host rocks (Fig.1B), indicating a rock-buffered fluid system during calcite precipitation in the early vug porosity and also during formation of F1 to F3. In contrast, in calcite cements $\mathrm{Cc} 5$ and $\mathrm{Cc} 6$, the $\delta^{18} \mathrm{O}$ is gradually more depleted with respect to their adjacent carbonate host rocks, indicating the opening of the system to exotic fluids as F4 to F7 formed (Fig.1B). This trend has already been reported in other areas of the SPFTB like the Jaca, Vallfogona and L'Escala thrusts, Ainsa Basin and Puig-reig anticline $[2,6,7]$ as well as in other orogens worldwide such as the Bighorn Basin and North Oman and Canadian Rocky Mountains [2, 8, 9], were it has been interpreted as the input of upward migrating hot and saline fluids mixed at depth with progressively more abundant meteoric waters, probably linked to the emersion of the structure.

\section{Conclusions}

During the early compression of the LPTS, fluids in equilibrium with their adjacent host rock migrated along N-S and E-W bed-perpendicular veins and bed-parallel slip surfaces. The progressive precipitation of $\delta^{18} \mathrm{O}$-depleted calcite cements in the faults 
formed during the late stages of compression, indicate the input of external fluids into the system. This evolution of fluid behavior, also observed in other areas of the SPFTB and worldwide, is interpreted as the input of hot and saline fluids mixed at depth with progressively more abundant meteoric waters during the emersion of the structure.

\section{Acknowledgements}

The isotopes were carried out at CCiTUB of the Universitat de Barcelona. This research was funded by the projects CGL2015-66335-C2-1-R and 2017SGR-824.

\section{References}

1. Roure, F., Andriessen, P., Callot, J.P., Faure, J.L., Ferket, H., Gonzales, E., Guilhaumou, N., Lacombe, O., Malandain, J., Sassi, W., Schneider, F., Swennen, R. and Vilasi, $\mathrm{N}$. The use of paleo-thermo-barometers and coupled thermal, fluid flow and pore-fluid pressure modelling for hydrocarbon and reservoir prediction in fold and thrust belts. In: G.P. Goffey, J. Craig, T. Needham and R. Scott (Eds.), Hydrocarbons in Contractional Belts. Geological Society, London, Spec. Pub., pp. 87-114 (2010).

2. Cruset, D., Cantarero, I., Vergés, J., John, C. M., Muñoz-López, D., Travé, A. Changes in fluid regime in syn-orogenic sediments during the growth of the south Pyrenean fold and thrust belt. Global \& Planetary Change. https://doi.org/10.1016/j.gloplacha.2017.11.001 (2017).

3. Vergés, J. Estudi geològic del vessant sud del Pirineu oriental i central. Evolució 947 cinemàtica en 3D, PhD thesis, Universitat de Barcelona, 203 pp (1993).

4. Burbank, D.W., Vergés, J., Muñoz, J.A. and Bentham, P. Coeval hinward- and forward-imbricating thrusting in the south-central Pyrenees, Spain: Timing and rates of shortening and deposition. Geological Society of America Bulletin, 104, 3-17 (1992).

5. Casini, G., Gillespie, P.A., Vergés, J., Romaire, I., Fernández, N., Casciello, E., Saura, E., Mehl, C., Homke, S., Embry, J.-C., Aghajari, L. and Hunt, D.W. Sub-seismic fractures in Foreland fold and Thrust belts: insight from the Lurestan Province, Zagros Mountains, Iran. Petroleum Geoscience, 17, 263-282 (2011).

6. Lacroix, B., Travé, A., Buatier, M., Labaume, P., Vennemann, T. and Dubois, M. Syntectonic fluid-flow along thrust faults: Example of the South-Pyrenean fold-andthrust belt. Marine and Petroleum Geology, 49, 84-98 (2014).

7. Travé, A., Labaume, P., Calvet, F., Soler, A. Sediment dewatering and pore fluid migration along thrust faults in a foreland basin inferred from isotopic and elemental geochemical analyses (Eocene Southern-Pyrenees, Spain). Tectonophysics, 282, 375-398 (1997).

8. Beaudoin, N., Bellahsen, N., Lacombe, O., Emmanuel, L. and Pironon, J. Crustal-scale fluid flow during the tectonic evolution of the Bighorn Basin (Wyoming, USA). Basin Research, 26 (3), 403-435 (2014).

9. Breesch, L., Swennen, R. and Vincent, B. Fluid flow reconstruction in hanging and footwall carbonates: Compartmentalization by Cenozoic reverse faulting in the Northern Oman Mountains (UAE). Marine and Petroleum Geology, 26, 113-128 (2009). 